\title{
Biota communities influence on nutrients circulation in hyporheic zone-a case study in urban spring niches in Bialystok (NE Poland)
}

\author{
Elżbieta Jekatierynczuk-Rudczyk ${ }^{1}$ (D) $\cdot$ Katarzyna Puczko $^{1}$ (D) $\cdot$ Justyna Żukowska ${ }^{2} \cdot$ Anna Sawicka $^{1}$
}

Received: 23 February 2021 / Accepted: 16 September 2021 / Published online: 4 October 2021

(c) The Author(s) 2021

\begin{abstract}
Hyporheic zone (HZ) is an interstitial part of groundwater. Complex physical, chemical and biological processes in $\mathrm{HZ}$ impact water quality. We hypothesized that groundwater upwelling improves surface water with biogenic compounds in lowland spring niches, and it depends on among others biota communities. The research was conducted in two spring niches in suburbs of Białystok. Interstitial samples were collected with mini-piezometers. In the field, the physical parameters of water were examined, and the micro and macro elements were determined in the laboratory. The analysis of biota included: vascular plants and bryophytes, diatoms, macroinvertebrates and bacteria. The springs studied differed in their richness of organisms, which is associated with varying degrees of abiotic conditions and human transformation. In spring niche with high degree of naturalness were twice less nitrate ions in the surface water than in interstitial water, which indicates the assimilation of nitrate ions by plants growing on the bottom of the niche. Hydrophilic vegetation performs a stabilizing function by assimilating nitrogen compounds and contributing to a variation in nutrients concentration. Groundwater upwelling enrich surface water with DOC and TON. In spring niche No.1 with patches of vegetation, the largest number of macrozoobenthos was recorded. While, the heterogeneous bottom of spring niche No.2 affected the diversity of habitats, and greater biodiversity of benthic fauna. In interstitial waters, there were about twice as few bacteria as in spring waters. Psychrophilic bacteria were present in interstitial waters that influence natural hyporheic processes including circulation of organic matter in the microbiological loop and self-purification of water.
\end{abstract}

Keywords Hyporheic zone $\cdot$ Spring biota communities $\cdot$ Human impact $\cdot$ Water quality

\section{Introduction}

Hyporheic zone (HZ) is a place of surface water metabolic processes. $\mathrm{HZ}$ can provide a spectrum of subsurface habitats depending on the spatial distribution of upwelling

Katarzyna Puczko

k.puczko@uwb.edu.pl

Elżbieta Jekatierynczuk-Rudczyk

rudczyk@uwb.edu.pl

Justyna Żukowska

justynastolc@gmail.com

Anna Sawicka

annasawicka4@onet.pl

1 Department of Environmental Protection, Faculty of Biology, University of Bialystok, Ciołkowskiego 1J, 15-245 Białystok, Poland

2 Provincial Environmental Protection Inspectorate, Ciołkowskiego 2/3, 15-264 Białystok, Poland groundwater and downwelling surface water. According to the definition, $\mathrm{HZ}$ is an interstitial part of groundwater, where the physical and chemical characteristics of water are stable in space and time (Brunke and Gonser 1997; Ward 2016). Physical transformation processes in $\mathrm{HZ}$ include among others: hydraulic retention, surface and groundwater mixing, thermal fluctuations. Biological processes include microbiological decomposition, uptake nutrients by plants, decomposition of macrozoobenthos that induces large releases of phosphorus from sediments (Xing et al. 2021), and chemical include carbon and nutrient cycling. Biogeochemical transformation of chemical compounds in $\mathrm{HZ}$ is mostly caused by a change in redox conditions and the presence of microbial biofilms (Zhu et al. 2020; Knapp et al. 2018). Forms of nutrients are changing, that impact the fertility of surface waters (Krause et al. 2011). When groundwater combines with surface water in the HZ, the characteristics of water are blended. A new gradient is established especially for water contamination (Biksey and Gross 
2001). Species composition and abundance of bacteria, flora and fauna influence water quality (Jekatierynczuk-Rudczyk 2007).

Organisms associated with the spring niche are called crenobionts. Some of them have the prefix creno in their names, for example crenophytes as specialized plants that are highly tolerant of low water temperature and inhabit crenal (Puczko et al. 2018). Spring bryophytes include both species crenophytes and hygrophytic mosses and liverworts with a wider distribution in aquatic habitats (Heino et al. 2005). Many species of water bryophytes, due to their high sensitivity to changes in the aquatic environment, including water quality, are considered indicator species (Szoszkiewicz et al. 2010).

The importance of the HZ in waters with high naturalness is quite well known (Ward 2016; Zhu et al. 2020; Lawrence et al. 2013). The knowledge of functioning of the $\mathrm{HZ}$ in urban areas is fragmentary. The hyporheic processes are more complex when associated human impact (Lawrence et al. 2013). The degree of naturalness of the aquatic environment of $\mathrm{HZ}$ is therefore another important element resulting the quality of water. Organic and toxic pollution of surface waters participate in the exchange processes between groundwater and surface water. The HZ is characterized by greater stability compared to the benthic zone due to its capacity for water retention during dry and flood periods (Robertson and Wood 2010). However, this does not change the fact that allochthonous substances of anthropogenic origin introduced into water can interfere with natural processes and modify them.

Understanding the biogeochemical processes in transition zone between groundwater and surface waters in upwelling conditions is possible in subsurface water in the voids of a rock called pore waters. The springs (natural groundwater outflows) are such places. Natural groundwater outflows occur in areas with a well-preserved natural environment. In the lowlands, due to the slight differences in terrain, springs are quite rare, and even less often they occur in areas with a high transformation of the water cycle, including urbanized areas. That is why our research in urban lowland springs is unique. On this basis, we try to show the differences between the water quality in the hyporeic zone, the spring niche and in the initial section of the river. Additionally, we seek to determine biota communities influence to nutrients circulation in hyporheic zone. We hypothesized that groundwater upwelling improves surface water with biogenic compounds, and it depends on the biota communities.

\section{Study area}

The research was conducted in the suburban area of Białystok. The Białystok city lies in the Podlasie province, in the north-eastern part of Poland. The city is situated in the Białystok Upland of the Podlaskie Plain. The region is characterised by high natural values, and is part of what is known as the Green Lungs of Poland. In hydrological terms, the study area belongs to the Vistula River catchment and the Baltic Sea basin. Białystok city is situated within the fourth-order catchment, including the Biała River and Jaroszówka River (Figs. 1 and 2). The southern part of the towns is drained by Horodnianka River. Horodnianka River is the right tributary of the Narew. Its length is $24.8 \mathrm{~km}$, and the catchment area is $76 \mathrm{~km}^{2}$. The Jaroszówka River is a left tributary of Supraśl River. The Jaroszówka River has a catchment area of $4.8 \mathrm{~km}^{2}$, of which $3.32 \mathrm{~km}^{2}$ within the city limits. River basin is characterized by a large slope (7.84\%o) and numerous springs. Complex hydrographic network owes its shape to varied terrain formed during the Weichselian glaciation. The area is characterized by the presence of moraine plateaus, the slopes of which are cut by numerous valleys. The area of the city is mostly deforested, and hydrological conditions are significantly changed. Despite the transformations of surface and groundwater, the Białystok region still has a well-preserved natural environment, which is confirmed by the presence of spring niches (Jekatierynczuk-Rudczyk 2008; Puczko and Jekatierynczuk-Rudczyk 2020). Two natural groundwater outflows with different geomorphological locations were selected for field tests. Both springs are supplied directly from groundwater, and groundwater is supplied in the water from rainfall or thawing snow. Spring

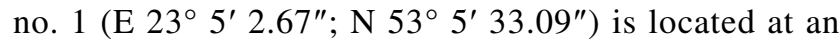
altitude of $141 \mathrm{~m}$ above sea level in the Turczyński Forest in the Horodnianka River catchment. It is an outflow with a shallowly indented longitudinal lenticular niche with an area of about $250 \mathrm{~m}^{2}$ and a depth of $0.5 \mathrm{~m}$. The aeration zone consists of sands and gravels. Mineral deposits in the discharge niche are covered with a thin layer of organic matter. The niche is surrounded by a mixed fresh forest composed of Pinus sylvestris, Carpinus betulus, Quercus robur. Bush layer is dominated by Corylus avellana. The bottom and edges of the spring niche seem to be intact and the human impact is low.

Spring no. 2 (E $23^{\circ} 11^{\prime} 57.87^{\prime \prime}$; N 53 $13^{\circ} 32.2^{\prime \prime}$ ) is located in the Jaroszówka River catchment at an altitude of $140 \mathrm{~m}$ above sea level. It is an outflow with a deeply indented threepart niche with slopes up to $3 \mathrm{~m}$. The aeration zone is made of various-grained sands, and the surrounding niche is a mixed forest. The bottom of the niche is almost completely devoid of vegetation partly caused by shading. The spring niche was a landfill site for many years. Now the garbage is lying under a thin layer of soil (Jekatierynczuk-Rudczyk 1999, 2008). The area around the spring has never been tidied up, the waste has been immobilized and overgrown with vegetation, and a thick layer of forest litter has effectively hidden huge trash heaps. 


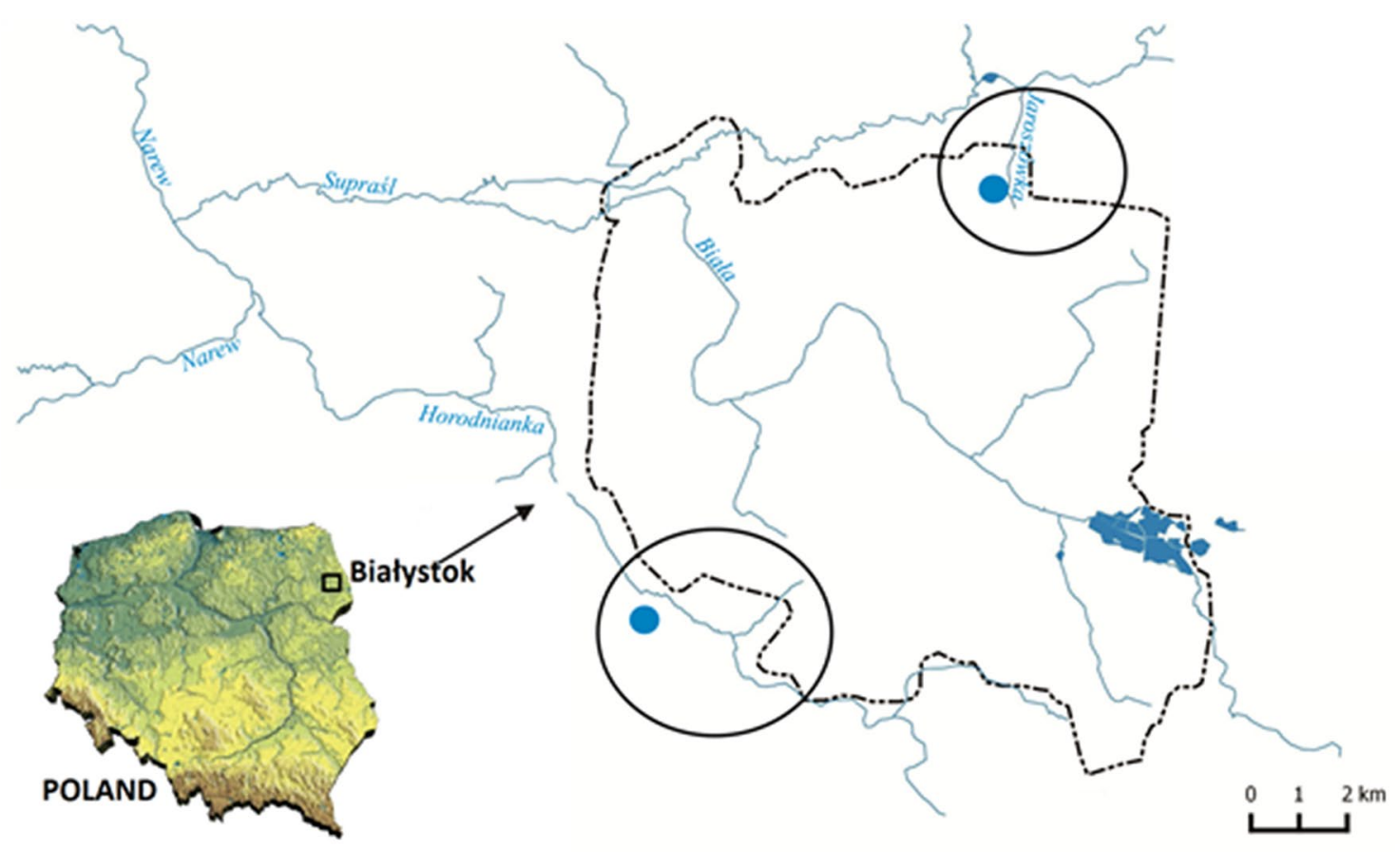

Fig. 1 Hydrographic map of Białystok with research areas marked with a circle

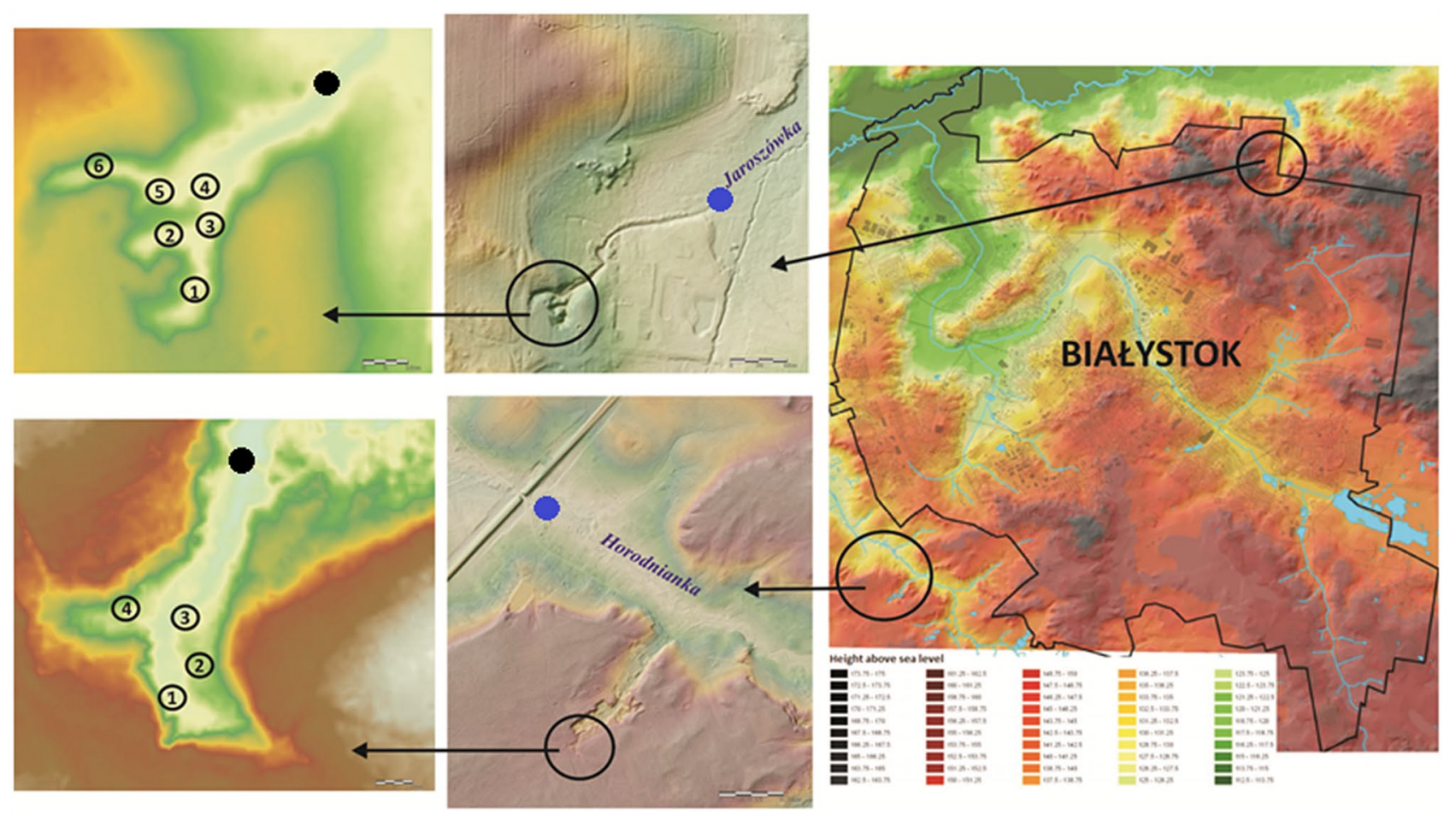

river water sample

spring water samlple 0 interstitial water samlple

Fig. 2 Hypsometric maps of spring niches in Białystok with sampling sites. Coordinates presented along the edges are in ETRS89/Poland CS92 


\section{Methods}

The research was conducted in 2019 at the beginning, in the middle and at the end of the growing season in monthly cycles from April to September. The average air temperature in April and September was $13^{\circ} \mathrm{C}$, in July and August it was $17^{\circ} \mathrm{C}$. The warmest month was June with an average air temperature of $20^{\circ} \mathrm{C}$. High monthly rainfall was in May, July and August and ranged from 100 to $114 \mathrm{~mm}$. In June and September, the sum of monthly precipitation did not exceed $55 \mathrm{~mm}$ (http://www.meteomodel.pl). Water samples from two springs were taken on the same days, so there were no differences in meteorological conditions during the sampling period.

Surface water was taken from a concentrated outflow within the spring niche and from the middle section of the river. Interstitial samples were collected with minipiezometers consisted of a $0.5 \mathrm{~m}$ long PVC tube. This allowed water collection from a depth of $30 \mathrm{~cm}$. The lower end was capped with a polyester mesh sized $0.1 \mathrm{~mm}$ to prevent sediment accumulation, and the upper end was capped with a rubber tip. A $5 \mathrm{~cm}$ strip of holes with a diameter of $4 \mathrm{~mm}$ was drilled in each piezometer. Four piezometers were placed in spring niche No. 1 , and six piezometers in spring niche No. 2 (Fig. 3). The spring niche No.2 has a branched shape, hence the greater number of samples. In total we collected 60 samples of interstitial water, 12 samples of spring water and 12 samples of river water. The type of outflow was determined on the basis of literature data (Jekatierynczuk- Rudczyk 1999, 2008, 2010) and using the Poncelet measuring overflow. The construction of aeration zone measured as the particle size distribution was determined by the organoleptic method. Spring niche measurements were conducted in field using simple measuring tools. The water circulation rate in the niche was estimated using piezometer pressure measurements. For this purpose, the water was pumped out of the piezometers using a vacuum pump and the filling time was measured. Measurements of piezometers filling time (P1-P4 in niche No.1 and P1-P6 in niche No.2) allowed determining the water circulation rate in various parts of the spring niche (Figs. 3 and 4).
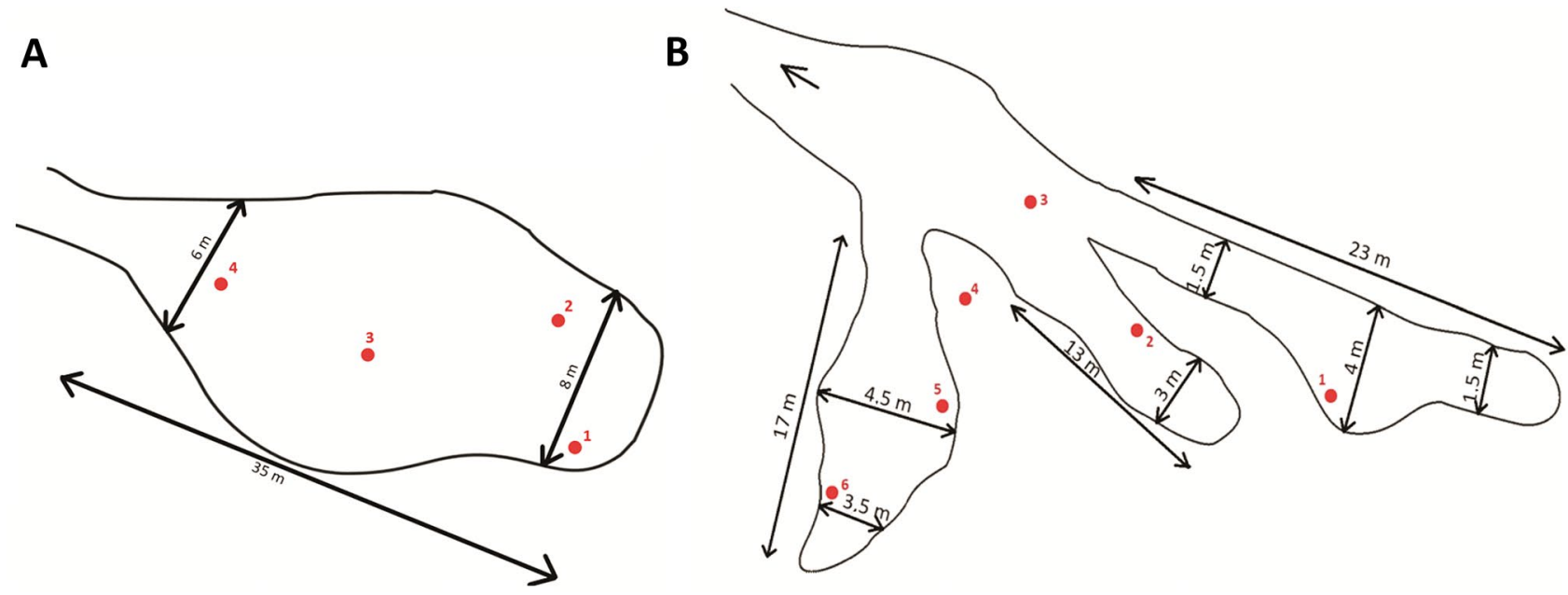

Fig. 3 Location schemes of piezometers in spring niches A (Horodnianka River catchment) and B(Jaroszówka River catchment)

Fig. 4 Variability of spring water yield in spring No. 1 (a) and spring No. 2 (b) in piezometers in from May to September (Q-water yield, $\mathrm{L} \mathrm{s}^{-1}$ )
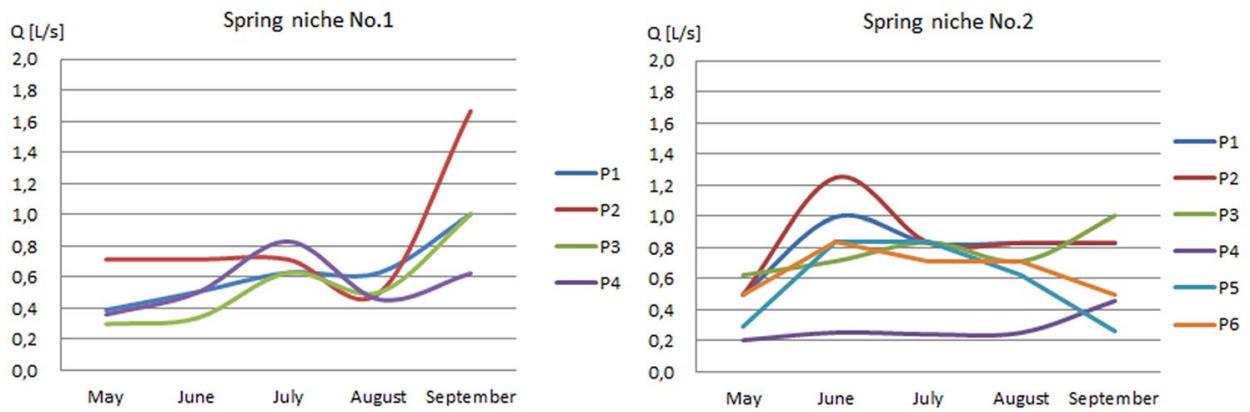


\section{Water quality data}

Water samples were collected once a month from April to September 2019. Basic physical and chemical water parameters: electrolytic conductivity (EC), temperature, oxygen saturation, $\mathrm{pH}$ and redox potential (Eh), were measured in the field by means of a HQ40 meter by Hach Lange probe. Total hardness, magnesium $\left(\mathrm{Mg}^{2+}\right)$, calcium $\left(\mathrm{Ca}^{2+}\right)$, sodium $\left(\mathrm{Na}^{+}\right)$, potassium $\left(\mathrm{K}^{+}\right)$, chlorides $\left(\mathrm{Cl}^{-}\right)$, sulfates $\left(\mathrm{SO}_{4}{ }^{2-}\right)$, ammonium nitrogen $\left(\mathrm{NH}_{4}{ }^{+}-\mathrm{N}\right)$ and nitrate nitrogen $\left(\mathrm{NO}_{3}{ }^{-} \mathrm{N}\right)$ were analysed using the HPLC method. The chromatographic set consisted of the following modules: System Gold 125 Solvent Module, 166 Detector, Autosampler 502 made by the Beckman Company, and a computer equipped with the System Gold PersonalTM Chromatograph program. Bicarbonates $\left(\mathrm{HCO}_{3}{ }^{-}\right)$were determined by titration with hydrochloric acid $(\mathrm{HCl})$ in the presence of an indicatormethyl orange (APHA 1998). Analyses of total organic carbon (TOC) and dissolved organic carbon (DOC) concentrations were carried out using the high-temperature catalytic combustion method with a Shimadzu carbon analyzer (TOC L, Japan). Particulate organic carbon (POC) was calculated as the difference between TOC and DOC concentrations. Total organic nitrogen (TON) was analysed by Tecator 2300 (Kjeldahl analyser). Phosphorus ions were determined by the molybdenum method. The total fraction (TP) was determined in non-filtered water after mineralisation. The reactive fraction (SRP) was determined in water filtered through a filter GF/F without prior mineralisation. Concentrations of the total iron (TFe) were analysed by applying the spectrophotometric method with 1,10-phenantroline in unfiltered water samples after UV digestion with concentrated sulphuric (VI) acid and 30\% hydrogen peroxide.

\section{Flora and fauna studies}

All plants were determined to the species level, and the quantity and sociability of individual plant species were determined using the Braun-Blanquet scale (Braun-Blanquet 1932). Taxonomic nomenclature of vascular plants was adopted based on Mirek et al. (2002), mosses according to Ochyra et al. (2003) and liverworts after Szweykowski (2006). Vascular plants were sampled in June.

Phytobenthos and zoobenthos were sampled once in June. Diatom phytobenthos has been chosen as one of biological quality elements to assess the ecological status of the spring niche and river. Epilithon was scraped and fixed in the field with $4 \%$ formaldehyde. Combined samples were collected from two spring niches and rivers, from at least five pebbles permanently immersed in the water. The pebbles in the river were selected along a line transverse to the river current and placed at equal intervals, with a total area of approx. From 5 to $10 \mathrm{~cm}^{2}$. In the spring niches, pebbles and small stones were collected in various parts of the niche in the outflow stream. Samples were collected until volume of $200 \mathrm{~mL}$ was obtained. Taxa were identified according to literature (Krammer and Lange-Bertalot 1986, 1991a, b, 1997). Basing on relative abundance of indicator species, the Polish diatom multimetric index IO (Picińska-Fałtynowicz et al. 2006) was calculated. The index is an average of three modules: the Trophic Index TI (Rott et al. 1999), the Saprobic Index SI (Rott et al. 1997) and the Abundance of Reference Species GR (Wasserwirtschaft 2005). The IO values have been proposed as follows: for ecological status high: $\mathrm{IO}>0.65$, good: 0.45 , moderate: 0.25 , poor: 0.10 and bad: $<0.10$.

Macroinvertebrates were collected from fine sediments with a plastic corer ( $4 \mathrm{~cm}$ in diameter), which was driven into the substratum to a depth of $5 \mathrm{~cm}$ ( 3 sub-samples were collected on each sampling site). Benthic invertebrates from all samples were sorted under a stereo-microscope and preserved in $4 \%$ formaldehyde. All taxonomic groups were identified to the family level. The Polish Multimetric Macroinvertebrate Index $\left(\mathrm{MMI}_{\mathrm{PL}}\right.$ ) (Lewin et al. 2014) was used to assess the ecological status.

In water samples, there were indicated microbiological parameters. The total viable counts of psychrophiles bacteria (TVC 22C) and mesophiles bacteria (TVC $37^{\circ} \mathrm{C}$ ) were described according to the norm PN-EN ISO 6222:2004. The total number of coliform bacteria were determined according to the norm PN-EN ISO 9308-1:2014-12. We also included in our research the number of fecal streptococci (enterococci), according to the norm PN-EN ISO 7899-2:2004 and the number of spore-forming bacteria of the Clostridium, according to the norm PN-EN ISO 14,189:2016-10.

\section{Statistical analyses}

The statistical analyses were conducted with the application of XLSTAT 2016.1 (https://www.xlstat.com/en/news/ version-2016-1). Standardised coefficients of variation $\left(C v=\frac{S D}{X} \times 100 \%\right)$; where SD is the standard deviation and $x$ is the sample mean) were calculated to compare the variability of water circulation. Spearman's rank correlation analysis was used to show the relationships among water quality variables in two springs. The statistical significance level was set at $p=0.05$ and $p=0.01$. The physical and chemical water parameters assigned to different water types (interstitial, spring and river) were compared among sampling sites using the analysis of variance (ANOVA), and Tukey's HSD (honestly significant difference) test was carried out to determine in which sites significant differences occurred. 


\section{Results}

\section{Water circulation dynamics in spring niches}

Both springs were characterized by yield not higher than $1.8 \mathrm{dm}^{3} \mathrm{~s}^{-1}$. In different parts of the niche (P1-P4 in niche No.1 and P1-P6 in niche No.2), the water circulation rate was variable (Fig. 4). The average of piezometers filling time in spring niche No. 1 was $0.65 \mathrm{dm}^{3} \mathrm{~s}^{-1}$, and in No. 2 was $0.75 \mathrm{dm}^{3} \mathrm{~s}^{-1}$. Spring niche No. 1 was characterized by greater average variability of water yield $(\mathrm{Cv}=47 \%)$ compered to spring niche No. $2(\mathrm{Cv}=40 \%)$. Cv values in piezometers in niche No. 1 were within $33 \%$ in $\mathrm{P} 4$ to $53 \%$ in P2. In niche No. 2 the variability of upwelling was in the range of 19\% in P3 to 49\% in P5. The highest water pressure was recorded in the central part of the niche of spring No. 1 in P2. Here, the maximum yield of 1.7 $\mathrm{dm}^{3} \mathrm{~s}^{-1}$ was observed in September. The lowest water yield was observed in May.

\section{Physical and chemical parameters of water}

River, spring and interstitial waters were characterized by different values of physical and chemical parameters (Table 1). The average water temperature in the studied interstitial water was $9.53{ }^{\circ} \mathrm{C}$, in springs $11.23{ }^{\circ} \mathrm{C}$ and in rivers $13.17{ }^{\circ} \mathrm{C}$. Oxygenation of the water increased significantly along the course of the river. In piezometers, water was 39\% (spring No.1) and 26\% (spring No.2) saturated with oxygen (Table 1). During the outflow, the water oxygenated and saturation values increased to around $90 \%$. A change in a colour of the water and the values of electrolytic conductivity were observed along the river course. Interstitial and stream waters in the Horodnianka catchment were characterized by low EC values compared to the Jaroszówka catchment, where values were twice as high. EC maxima exceeding $2000 \mu \mathrm{S} \mathrm{cm}^{-1}$ was observed in the spring No. 2 .

The composition of cations was dominated by calcium and magnesium ions, and the composition of anions by

Table 1 Water quality characteristic (mean value \pm standard deviation) of interstitial waters, springs and rivers studied (post hoc Tukey HSD test $(p<0.05))$

\begin{tabular}{|c|c|c|c|c|c|c|c|c|c|}
\hline \multirow[t]{4}{*}{ Parameter } & & \multicolumn{3}{|c|}{ Horodnianka River catchment } & \multirow{4}{*}{$\begin{array}{l}\text { Statistical } \\
\text { significance } \\
\text { of differ- } \\
\text { ences* }\end{array}$} & \multicolumn{3}{|c|}{ Jaroszówka River catchment } & \multirow{4}{*}{$\begin{array}{l}\text { Statistical } \\
\text { significance of } \\
\text { differences* }\end{array}$} \\
\hline & & \multirow{3}{*}{$\begin{array}{l}\text { Interstitial } \\
\text { water } \\
\text { a } \\
n=24\end{array}$} & \multirow{3}{*}{$\begin{array}{l}\text { Spring } \\
\mathrm{b} \\
n=6\end{array}$} & \multirow{3}{*}{$\begin{array}{l}\text { River } \\
\text { c } \\
n=6\end{array}$} & & \multirow{3}{*}{$\begin{array}{l}\text { Interstitial } \\
\text { water } \\
\text { a } \\
n=36\end{array}$} & \multirow{3}{*}{$\begin{array}{l}\text { Spring } \\
\mathrm{b} \\
n=6\end{array}$} & \multirow{3}{*}{$\begin{array}{l}\text { River } \\
\text { c } \\
n=6\end{array}$} & \\
\hline & & & & & & & & & \\
\hline & & & & & & & & & \\
\hline Temperature & ${ }^{\circ} \mathrm{C}$ & $9.09 \pm 1.19$ & $11.53 \pm 2.40$ & $13.43 \pm 3.77$ & $\mathrm{a}-\mathrm{c}$ & $9.83 \pm 1.44$ & $11.05 \pm 2.48$ & $12.90 \pm 3.90$ & $\mathrm{a}-\mathrm{c}$ \\
\hline Reaction & $\mathrm{pH}$ & $6.42 \pm 0.23$ & $6.52 \pm 0.23$ & $6.55 \pm 0.23$ & & $6.66 \pm 0.57$ & $6.97 \pm 0.20$ & $7.05 \pm 0.18$ & $\mathrm{a}-\mathrm{c}$ \\
\hline $\mathrm{EC}$ & $\mu \mathrm{S} \mathrm{cm}{ }^{-1}$ & $428 \pm 35$ & $397 \pm 9$ & $588 \pm 108$ & $\mathrm{a}-\mathrm{b} ; \mathrm{b}-\mathrm{c}$ & $1145 \pm 461$ & $898 \pm 41$ & $738 \pm 76$ & \\
\hline $\begin{array}{l}\text { Oxygen } \\
\text { saturation }\end{array}$ & $\%$ & $39 \pm 8$ & $81 \pm 4$ & $88 \pm 9$ & $a-c ; b-c$ & $26 \pm 11$ & $81 \pm 7$ & $90 \pm 11$ & $a-b ; a-c$ \\
\hline Eh & $\mathrm{mV}$ & $152 \pm 37$ & $154 \pm 32$ & $140 \pm 53$ & & $156 \pm 46$ & $145 \pm 42$ & $137 \pm 39$ & \\
\hline $\mathrm{Ca}^{2+}$ & $\mathrm{mg} \mathrm{L}^{-1}$ & $83 \pm 13$ & $74 \pm 13$ & $81 \pm 17$ & & $101 \pm 30$ & $117 \pm 22$ & $93 \pm 29$ & \\
\hline $\mathrm{Mg}^{2+}$ & $\mathrm{mg} \mathrm{L}^{-1}$ & $13 \pm 6$ & $14 \pm 8$ & $18 \pm 7$ & & $56 \pm 35$ & $35 \pm 18$ & $22 \pm 11$ & \\
\hline $\mathrm{Na}^{+}$ & $\mathrm{mg} \mathrm{L}^{-1}$ & $19.5 \pm 15$ & $13.2 \pm 0.5$ & $14.6 \pm 1.2$ & & $33.4 \pm 16.5$ & $53.1 \pm 17.4$ & $27.7 \pm 6.8$ & \\
\hline $\mathrm{K}^{+}$ & $\mathrm{mg} \mathrm{L}^{-1}$ & $0.87 \pm 0.44$ & $0.72 \pm 0,12$ & $3.27 \pm 1.85$ & $a-c ; b-c$ & $6.8 \pm 3.6$ & $6.6 \pm 1.5$ & $2.4 \pm 0.5$ & \\
\hline $\mathrm{HCO}_{3}^{-}$ & $\mathrm{mgC} \mathrm{L}^{-1}$ & $281 \pm 26$ & $258 \pm 11$ & $308 \pm 49$ & $a-c ; b-c$ & $507 \pm 77$ & $466 \pm 18$ & $337 \pm 51$ & $\mathrm{a}-\mathrm{c} ; \mathrm{b}-\mathrm{c}$ \\
\hline $\mathrm{SO}_{4}{ }^{2-}$ & $\mathrm{mg} \mathrm{L}^{-1}$ & $32.7 \pm 8.7$ & $38.2 \pm 3.4$ & $38.5 \pm 7.5$ & & $113.6 \pm 75.5$ & $130.5 \pm 12.1$ & $65.5 \pm 10.9$ & \\
\hline $\mathrm{Cl}^{-}$ & $\mathrm{mg} \mathrm{L}^{-1}$ & $5.5 \pm 2.3$ & $5.5 \pm 1.0$ & $26.1 \pm 16.9$ & $a-c$ & $144.9 \pm 217.7$ & $88.6 \pm 34.0$ & $71.2 \pm 15.2$ & \\
\hline $\mathrm{TFe}$ & $\mathrm{mg} \mathrm{L}^{-1}$ & $0.06 \pm 0.1$ & $0.1 \pm 0.1$ & $0.04 \pm 0.03$ & & $0.04 \pm 0.03$ & $0.03 \pm 0.01$ & $0.03 \pm 0.03$ & \\
\hline DOC & $\mathrm{mg} \mathrm{L}^{-1}$ & $1.85 \pm 0.71$ & $2.62 \pm 0.6$ & $8.50 \pm 3.42$ & $a-c ; b-c$ & $2.41 \pm 0.56$ & $2.59 \pm 0.25$ & $3.48 \pm 0.55$ & \\
\hline POC & $\mathrm{mg} \mathrm{L}^{-1}$ & $1.18 \pm 2.49$ & $1.88 \pm 2.47$ & $0.40 \pm 0.44$ & $a-c$ & $0.36 \pm 0.33$ & $2.54 \pm 5.60$ & $0.90 \pm 1.22$ & \\
\hline $\mathrm{NH}_{4}^{+}-\mathrm{N}$ & $\mathrm{mg} \mathrm{L}^{-1}$ & $0.1 \pm 0.09$ & $0.07 \pm 0.09$ & $0.12 \pm 0.13$ & & $0.09 \pm 0.09$ & $0.06 \pm 0.09$ & $0.11 \pm 0.10$ & \\
\hline $\mathrm{NO}_{3}{ }^{-}-\mathrm{N}$ & $\mathrm{mg} \mathrm{L}^{-1}$ & $0.28 \pm 0.23$ & $0.13 \pm 0.07$ & $0.69 \pm 0.72$ & & $3.63 \pm 2.59$ & $2.09 \pm 1.08$ & $4.89 \pm 2.57$ & \\
\hline TON & $\mathrm{mg} \mathrm{L}^{-1}$ & $0.49 \pm 0.29$ & $1.28 \pm 0.95$ & $2.12 \pm 1.25$ & $a-c ; b-c$ & $3.05 \pm 2.61$ & $3.69 \pm 5.17$ & $4.86 \pm 1.61$ & \\
\hline SRP & $\mathrm{mg} \mathrm{L}^{-1}$ & $0.05 \pm 0.03$ & $0.05 \pm 0.02$ & $0.02 \pm 0.02$ & & $0.03 \pm 0.02$ & $0.03 \pm 0.01$ & $0.01 \pm 0.01$ & \\
\hline $\mathrm{TP}$ & $\mathrm{mg} \mathrm{L}^{-1}$ & $0.12 \pm 0.09$ & $0.10 \pm 0.07$ & $0.08 \pm 0.03$ & & $0.09 \pm 0.05$ & $0.113 \pm 0.09$ & $0.1 \pm 0.08$ & \\
\hline
\end{tabular}

*Tukey (HSD)/analysis of the differences between the categories with a confidence interval of $95 \%$ 
Table 2 Results of the Spearman's rank correlation analysis of water quality variables in Horodnianka River catchment (blue grates) and Jaroszówka River catchment (green grates)

\begin{tabular}{|c|c|c|c|c|c|c|c|c|c|c|c|c|c|c|c|c|c|c|c|c|}
\hline & 槖 & \pm & U. & 醇 & 表 & స̃ & $\sum_{\sum}^{+\infty}$ & ${ }^{+\pi}$ & \pm & $e_{0}^{1}$ & $\stackrel{\leftrightarrow}{0}$ & $\frac{1}{U}$ & $\stackrel{9}{10}$ & ஜ & 巳 & 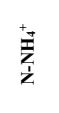 & $\begin{array}{l}0_{2}^{\prime} \\
\frac{1}{2} \\
2\end{array}$ & ż & $\hat{\bar{w}}$ & 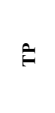 \\
\hline Temperature & 1.00 & 0.58 & -0.34 & 0.60 & 0.31 & 0.07 & -0.03 & 0.03 & -0.13 & -0.27 & -0.57 & -0.29 & 0.49 & 0.07 & 0.15 & 0.11 & 0.41 & 0.31 & 0.15 & -0.34 \\
\hline pH & 0.47 & 1.00 & -0.49 & 0.54 & -0.23 & -0.21 & -0.01 & -0.03 & 0.06 & 0.11 & -0.53 & -0.51 & 0.54 & -0.17 & -0.27 & 0.46 & -0.16 & -0.05 & 0.04 & -0.45 \\
\hline EC & 0.72 & 0.05 & 1.00 & -0.36 & 0.09 & 0.53 & -0.12 & -0.42 & -0.31 & 0.03 & 0.74 & 0.33 & -0.23 & 0.21 & 0.12 & -0.41 & 0.25 & -0.08 & -0.18 & 0.70 \\
\hline $\begin{array}{l}\begin{array}{l}\text { Oxygen } \\
\text { saturation }\end{array} \\
\end{array}$ & 0.78 & 0.31 & 0.62 & 1.00 & -0.15 & -0.10 & -0.17 & -0.06 & -0.25 & -0.50 & -0.59 & 0.11 & 0.26 & -0.28 & 0.13 & 0.02 & -0.22 & 0.14 & 0.19 & -0.53 \\
\hline Eh & -0.05 & 0.24 & -0.37 & -0.31 & 1.00 & -0.16 & 0.10 & 0.07 & 0.27 & 0.16 & 0.04 & 0.13 & 0.17 & 0.32 & -0.31 & -0.45 & 0.69 & 0.06 & -0.35 & 0.26 \\
\hline $\mathrm{Ca}^{2+}$ & 0.29 & 0.06 & 0.47 & 0.49 & -0.90 & 1.00 & 0.32 & 0.19 & -0.19 & -0.17 & 0.51 & -0.06 & 0.11 & -0.13 & 0.24 & 0.15 & 0.00 & 0.16 & 0.20 & 0.48 \\
\hline $\mathrm{Mg}^{2+}$ & -0.30 & 0.18 & -0.05 & -0.40 & 0.13 & -0.08 & 1.00 & 0.90 & 0.58 & 0.15 & 0.16 & -0.13 & 0.25 & -0.07 & 0.09 & 0.12 & -0.08 & -0.06 & -0.19 & 0.19 \\
\hline $\mathrm{Na}^{+}$ & 0.00 & 0.36 & 0.29 & 0.03 & -0.36 & 0.52 & 0.75 & 1.00 & 0.55 & -0.05 & -0.04 & -0.06 & 0.26 & -0.20 & -0.27 & 0.14 & -0.14 & 0.16 & 0.08 & -0.04 \\
\hline $\mathbf{K}^{+}$ & -0.24 & 0.40 & -0.21 & -0.42 & 0.43 & -0.30 & 0.83 & 0.58 & 1.00 & 0.57 & 0.05 & -0.37 & 0.18 & -0.09 & -0.04 & 0.37 & -0.24 & -0.32 & -0.38 & 0.21 \\
\hline $\mathrm{HCO}_{3}^{-}$ & 0.32 & 0.22 & 0.57 & 0.39 & -0.75 & 0.87 & 0.21 & 0.73 & 0.01 & 1.00 & 0.28 & -0.56 & -0.03 & -0.07 & -0.27 & 0.43 & -0.21 & -0.61 & -0.58 & 0.45 \\
\hline $\mathrm{SO}_{4}{ }^{2-}$ & 0.45 & -0.29 & 0.82 & 0.41 & -0.54 & 0.59 & -0.24 & 0.18 & -0.38 & 0.52 & 1.00 & 0.05 & 0.05 & 0.02 & -0.09 & -0.24 & -0.07 & -0.30 & -0.29 & 0.83 \\
\hline Cl- & 0.15 & 0.10 & 0.29 & 0.23 & 0.03 & -0.06 & 0.35 & 0.25 & 0.01 & 0.20 & -0.14 & 1.00 & -0.45 & -0.01 & -0.18 & -0.75 & 0.18 & 0.50 & 0.34 & -0.03 \\
\hline TFe & 0.85 & 0.11 & 0.82 & 0.60 & 0.11 & 0.03 & -0.23 & -0.15 & -0.21 & 0.11 & 0.56 & 0.21 & 1.00 & 0.15 & 0.07 & 0.05 & 0.11 & -0.14 & -0.17 & -0.09 \\
\hline DOC & -0.21 & -0.22 & -0.13 & 0.07 & -0.10 & -0.18 & -0.19 & -0.27 & -0.34 & -0.27 & -0.14 & 0.23 & -0.17 & 1.00 & 0.19 & -0.32 & 0.64 & -0.14 & -0.31 & -0.20 \\
\hline POC & -0.14 & -0.26 & -0.15 & 0.19 & -0.19 & -0.18 & -0.04 & -0.31 & -0.24 & -0.17 & -0.13 & 0.18 & -0.09 & 0.12 & 1.00 & -0.12 & -0.42 & -0.08 & -0.06 & -0.19 \\
\hline $\mathrm{N}-\mathrm{NH}_{4}{ }^{+}$ & 0.65 & 0.19 & 0.82 & 0.65 & -0.71 & 0.84 & -0.08 & 0.46 & -0.27 & 0.89 & 0.73 & 0.19 & 0.50 & -0.21 & -0.12 & 1.00 & -0.53 & -0.24 & 0.07 & -0.13 \\
\hline $\mathrm{N}-\mathrm{NO}_{3}{ }^{-}$ & 0.12 & 0.72 & 0.09 & 0.31 & 0.77 & -0.51 & 0.56 & 0.77 & 0.70 & 0.18 & -0.33 & 0.16 & -0.39 & -0.04 & -0.05 & -0.59 & 1.00 & 0.36 & -0.03 & 0.04 \\
\hline TON & 0.65 & 0.17 & 0.67 & 0.37 & 0.38 & -0.25 & -0.04 & -0.09 & -0.02 & -0.14 & 0.40 & 0.29 & 0.86 & -0.07 & 0.29 & 0.20 & 0.60 & 1.00 & 0.88 & -0.23 \\
\hline SRP & 0.58 & 0.23 & 0.76 & 0.64 & -0.74 & 0.87 & -0.11 & 0.49 & -0.31 & 0.89 & 0.71 & 0.17 & 0.38 & -0.11 & -0.15 & 0.97 & 0.04 & 0.15 & 1.00 & -0.36 \\
\hline TP & -0.20 & 0.22 & -0.24 & -0.10 & 0.63 & -0.51 & 0.36 & 0.11 & 0.41 & -0.45 & -0.43 & 0.34 & -0.13 & 0.08 & -0.27 & -0.53 & 0.85 & 0.30 & -0.46 & 1.00 \\
\hline
\end{tabular}

The correlation coefficients marked in red are significant with $\mathrm{p}<0.05$

Fig. 5 Charts of organic carbon content: dissolved fraction (DOC) and particular fraction (POC) in interstitial and surface water from April to September in both spring niches and rivers (A-Horodnianka River catchment and B-Jaroszówka River catchment)
A Horodnianka catchment
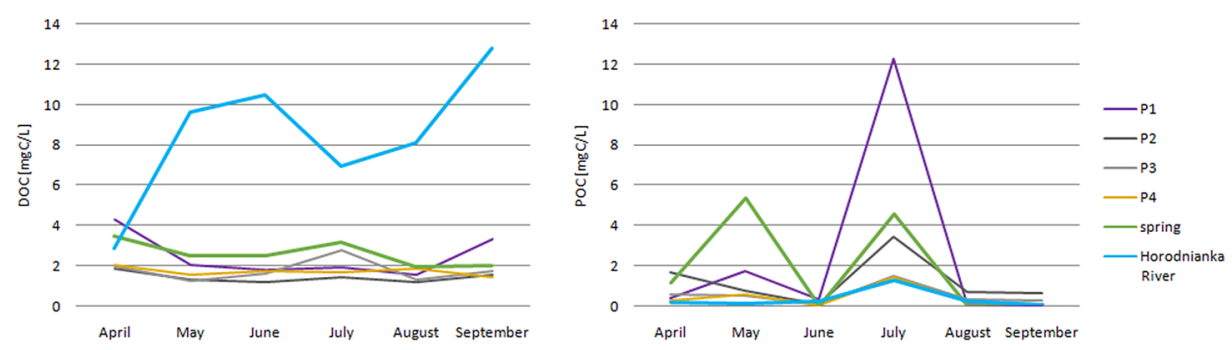

B Jaroszówka catchment

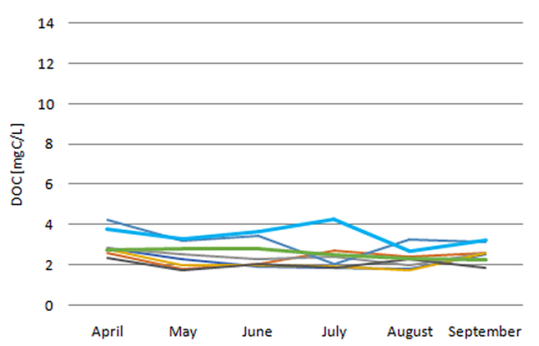

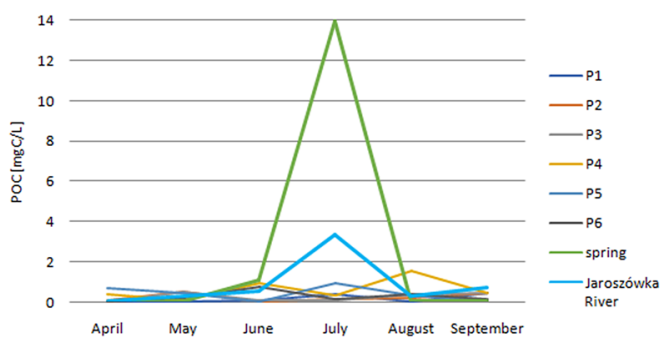


bicarbonate ions (Table 1). Based on the analysis of Spearman's rank correlation, it was observed that in the Horodnianka River catchment area there were more significant relationships between the physical parameters of water (temperature, electrolytic conductivity as well as oxygen and redox conditions), and the content of dissolved organic carbon (DOC) and organic nitrogen (TON). Single positive correlations between EC and SRP and between redox potential and ammonium ions were observed. In the Jaroszówka River catchment such correlations were significantly less (Table 2).

Interstitial water of spring No. 1 was characterized by small concentration of DOC and its amount increased significantly when the water cycle changes from underground to surface. Detailed data on the content of DOC and POC are presented in Fig. 5. During the research, the dynamics of changes in the concentration of organic carbon forms was low, except for July, when high concentrations of POC fraction were noted.

A high variety in the concentration of nitrogen compounds was observed in all types of water examined. The highest concentration of ammonium ions, nitrates (V) and organic nitrogen was recorded in rivers. In interstitial waters of both springs, high concentration of ammonium and nitrate ions was recorded compared to their content in the outflow. In spring No. 1, there were twice less nitrate ions in the surface water than in interstitial water (Fig. 6). In spring No. 2, there were observed higher concentration of nitrates in the interstitial waters compared to spring water. Organic nitrogen (TON) predominated in the structure of nitrogen compounds in all studied types of water.
The TP concentration in the examined waters was 0.1 $\mathrm{mgP} \mathrm{L}^{-1}$ on average, and about $0.05 \mathrm{mgP} \mathrm{L}^{-1}$ orthophosphate. No significant differences were observed in the content of phosphorus compounds in interstitial and surface waters (Tukey test, $\mathrm{p}>0.05$ ).

\section{Spring niches flora, fauna and microbial community}

The structure of diatom communities consists of 78 taxa of diatoms found in both sampling sites (Table 3 ). The most numerous genera were: Navicula (14 taxa), Nitzschia (13), Amphora (7), Planothidium (5). In the Horodnianka River catchment, the calculated TI index for river proves a high trophic level (3.09). The TI values calculated for Spring No.1 and Jaroszówka River and spring No.2 points to a medium trophic level (meso-eutrophy). The SI values values in all sampling sites were within the range 1.23-2.16 and corresponded to $\beta$-mesosaprobic. The multimetric diatom index IO indicated good ecological status of both springs and Jaroszówka River. The Horodnianka River was characterised by a moderate status (Table 4 ).

In total, 19 species of vascular plants and five species of mosses and 1 species of liverwort were recorded from two spring niches (Table 5). Spring niche No. 1 was characterized by a greater species richness of plants. At the peak of the growing season, at the turn of June and July, vegetation grew $75 \%$ of the niche's bottom surface. The dominant species were Veronica beccabunga and Nasturtium officinale. Large clusters of Lemna minor and Lemna trisulca were also observed. The bryophytes formed irregular clusters with a compact composition mainly of three species: Brachytecium
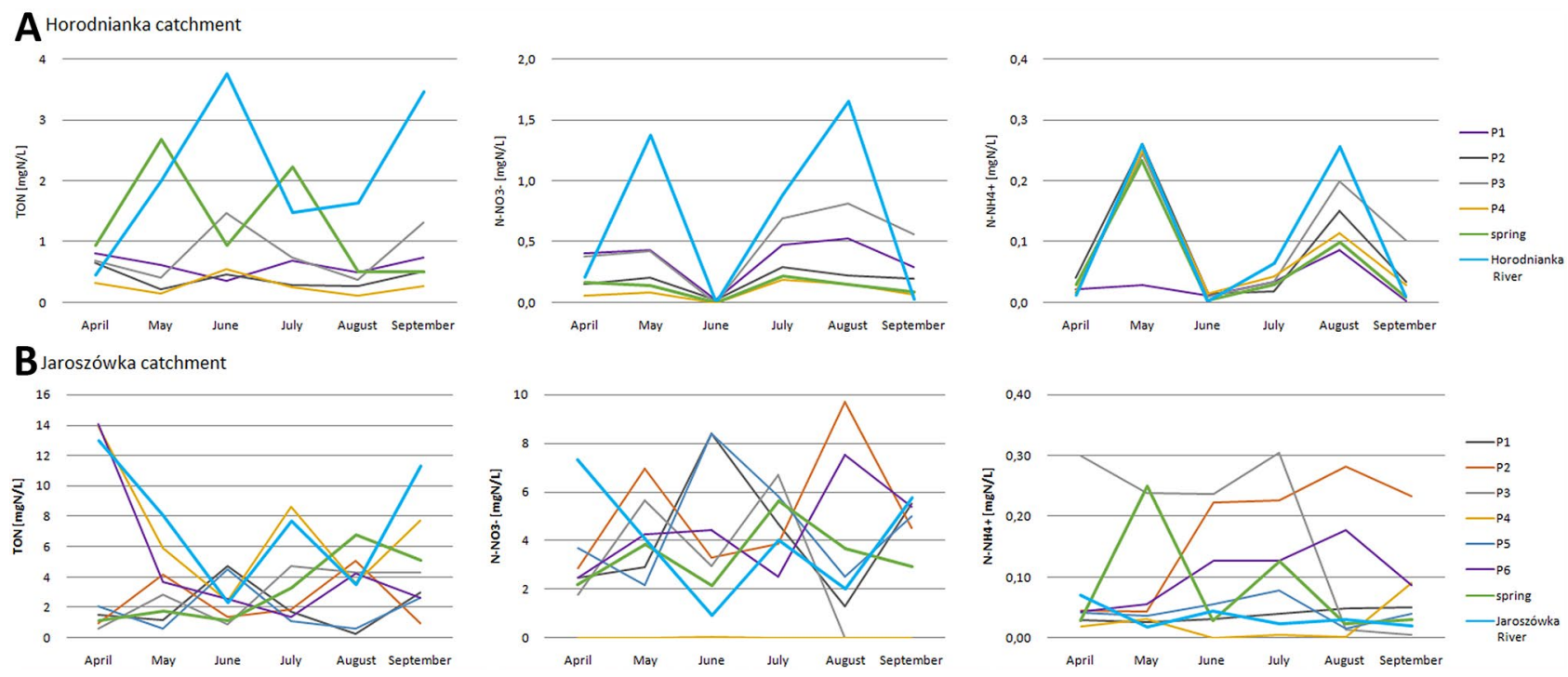

Fig. 6 Charts of organic nitrogen, nitrate nitrogen and ammonium concentrations in interstitial and surface water from April to September in both spring niches and rivers (A-Horodnianka River catchment and B-Jaroszówka River catchment) 


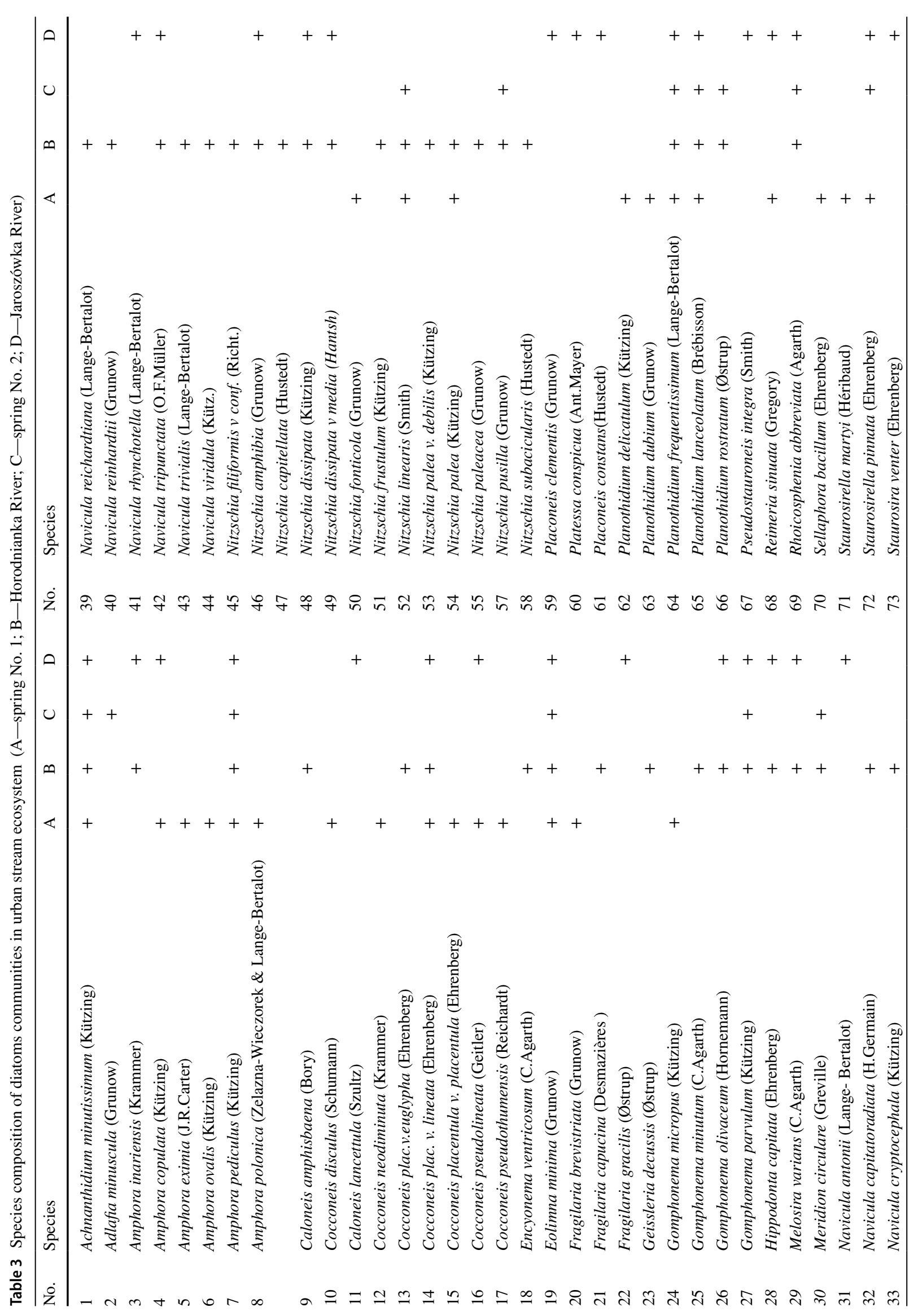




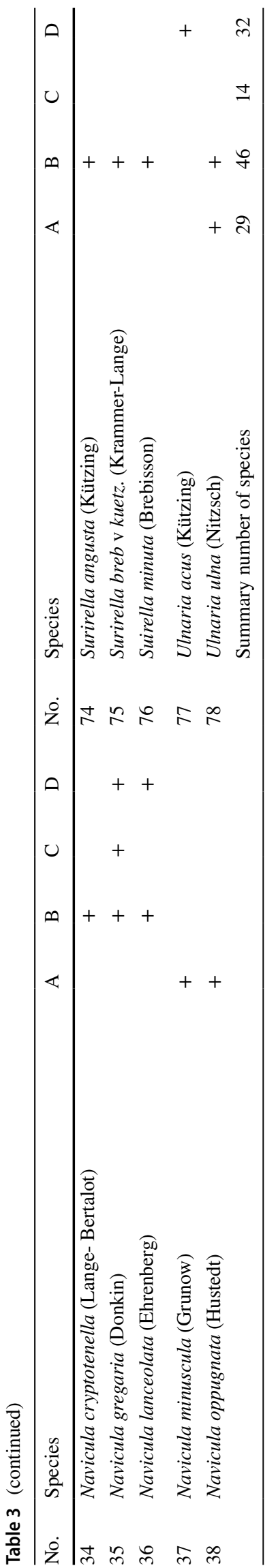

Table 4 Ecological status of studied sites according to diatom multimetric index IO

\begin{tabular}{llllll}
\hline & TI & SI & GR & IO & Ecological state \\
\hline Spring no. 1 & 2.65 & 1.23 & 0.64 & 0.63 & Good \\
Horodnianka & 3.09 & 2.16 & 0.39 & 0.41 & Moderate \\
Spring no. 1 & 2.89 & 1.98 & 0.94 & 0.63 & Good \\
Jaroszówka & 2.64 & 2.02 & 0.84 & 0.62 & Good \\
\hline
\end{tabular}

rivulare, Plagiomnium undulatum and Rhizomnium punctatum. Few plant species were noted in spring niche No. 2 . Bottom of the niche was shaded and overgrown with only a few single common species typical of moist habitats and forests. A single, small patch of vegetation of Nasturtium officinale was observed in the central part of the niche. Only two species were represented by bryophyte flora: Plagiomnium undulatum and Leptodictyum riparium.

Spring niches benthic fauna was represented by 12 orders (Table 6; Fig. 7) and 36 families in total. $\mathrm{MMI}_{\mathrm{PL}}$ values indicate good ecological status of both springs and Horodnianka River, and poor ecological status of Jaroszówka River. Spring No.1 was characterized by the largest number of invertebrates (281) belonging to 10 families. Spring No. 2 was characterized by the greatest richness of taxa ( 23 families represented by 172 individuals). In rivers there were 138 (Jaroszówka) and 139 (Horodnianka) individuals of invertebrates belonging to 10 and 13 families.

Microbiological analysis carried out in spring niches and in the Horodnianka and Jaroszówka rivers indicate greater bacteriological pollution of rivers compared to spring areas (Table 7). River water was characterized by over 10,000 CFU of TVC, while in interstitial water the number of TVC was less than $1000 \mathrm{CFU}$. In addition, in river water were observed fecal streptococci and Clostridium with spores. Interstitial waters were characterised by the lowest number of bacteria compared to surface waters.

\section{Discussion}

Springs are good objects for studying changes in the quality of groundwater flowing out to the surface. With the springs it is possible to control the characteristics of the water quality in the final step of the underground phase and the initial stage of the surface phase of her cycle (Jekatierynczuk-Rudczyk 2010). The conducted research confirmed that springs are a unique ecotone with specific physical and chemical attributes, living organisms, energy and material flow processes (Barquín and Scarsbrook 2008). Biota communities living in spring niches influence water quality, especially nutirents. The concentrations of nitrogen, phosphorous and organic carbon varied in space and time. 
Table 5 Species of vascular plants and bryophytes found in spring niches with relative abundance and sociability (abund., soc.)

\begin{tabular}{|c|c|c|c|c|c|c|}
\hline & Vascular plants & Abund. & Soc. & Bryophytes & Abund. & Soc. \\
\hline \multirow[t]{15}{*}{ Spring niche no. 1} & Athyrium filix-femina L. Roth & + & 2 & Brachytecium rivulare Schimp. & 1 & 2 \\
\hline & Equisetum fluviatile L. em. Ehrh. & + & 1 & Plagiomnium undulatum Hedw. T.J. Kop. & 1 & 1 \\
\hline & Epilobium palustre $\mathrm{L}$. & + & 1 & Rhizomnium punctatum Hedw. T.J. Kop & 1 & 1 \\
\hline & Galium palustre $\mathrm{L}$. & + & 2 & Hypnum cupressiforme Hedw. & + & 1 \\
\hline & Lemna minor $\mathrm{L}$. & 2 & 4 & Pellia neesiana Gottsche Limpr. & + & 1 \\
\hline & Lemna trisulca $\mathrm{L}$. & 2 & 4 & & & \\
\hline & Lysimachia vulgaris $\mathrm{L}$. & + & 1 & & & \\
\hline & Mentha aquatica $\mathrm{L}$. & 1 & 2 & & & \\
\hline & Nasturtium officinale W. T. Aiton & 2 & 2 & & & \\
\hline & Oxalis acetoosella $\mathrm{L}$. & 1 & 2 & & & \\
\hline & Veronica beccabunga $\mathrm{L}$. & 2 & 2 & & & \\
\hline & Poa palustris L. & + & 1 & & & \\
\hline & Ranunculus repens $\mathrm{L}$. & + & 1 & & & \\
\hline & Persicaria amphibia L. Delabre. & + & 1 & & & \\
\hline & Myosotis scorpioides L. & + & 1 & & & \\
\hline \multirow[t]{7}{*}{ Spring niche no. 2} & Cirsium oleraceum L. Scop. & + & 2 & Plagiomnium undulatum Hedw. T.J. Kop. & + & 1 \\
\hline & Equisetum palustre $\mathrm{L}$. & + & 1 & Leptodictyum riparium Hedw. Warnst. & + & 1 \\
\hline & Stellaria holostea $\mathrm{L}$. & + & 1 & & & \\
\hline & Nasturtium officinale W. T. Aiton & 1 & 3 & & & \\
\hline & Oxalis acetoosella $\mathrm{L}$. & 1 & 1 & & & \\
\hline & Equisetum fluviatile L. em. Ehrh. & + & 1 & & & \\
\hline & Ranunculus repens $\mathrm{L}$. & + & 1 & & & \\
\hline
\end{tabular}

Fig. 7 Relative abundances of major macroinvertebrate communities dominating in sediment samples collected in springs No. 1,2 and Horodnianka River and Jaroszówka River

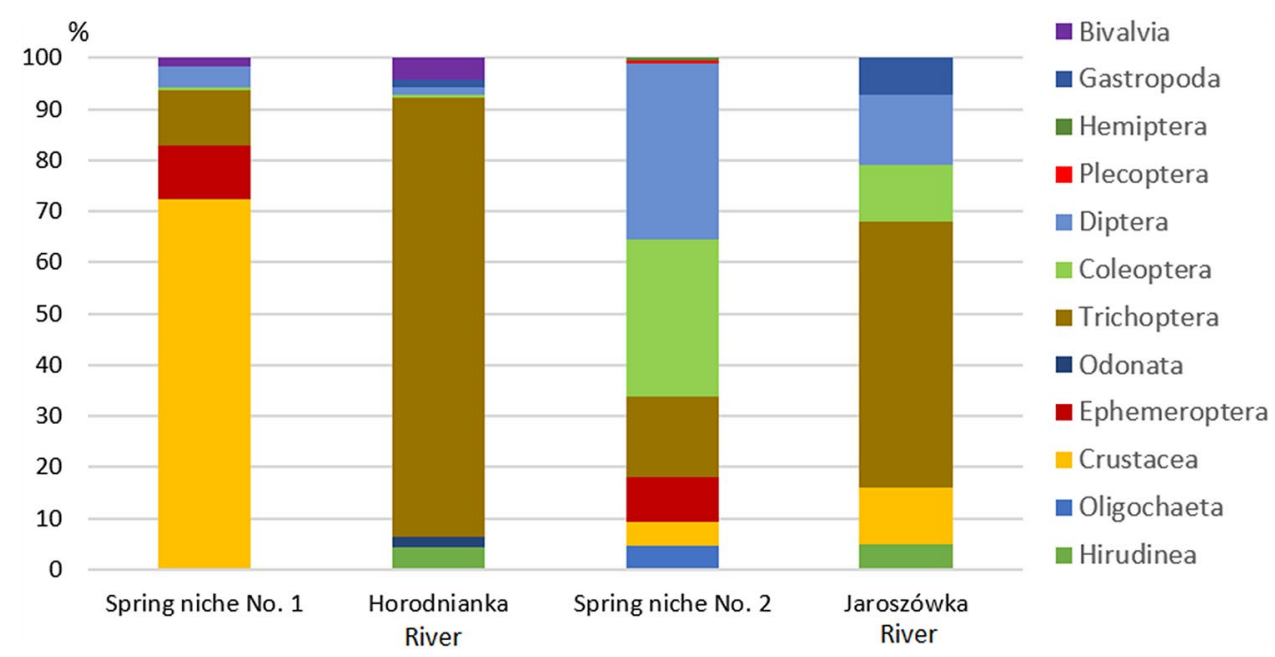

Springs studied are characterized by a thaw regime and low water circulation with yield fluctuations typical of north-eastern Poland (Jekatierynczuk-Rudczyk 2008, 2007; Górniak and Jekatierynczuk-Rudczyk 1997). Shortterm summer rainfalls do not result in an increase in spring water yield. Rainfall in May, July and August was on average $30 \mathrm{~mm}$ higher compared to the average rainfall in these months from the years 1991-2020 (https://meteomodel.pl). Despite the increase in the amount of rainfall, no change in the dynamics of water outflow was observed. High air temperature results in low infiltration and increased evaporation in the summer. Increased water yield could be the result of infiltration during intense and continuous rainfall (Sojka et al. 2020). Furthermore, the geological structure of the aeration zone or the land use can result the water yield fluctuations and water quality (Puczko et al. 2018).

Both spring niches differed in water quality (Table 1). Pollution flows to the spring in the Jaroszówka catchment, 
Table 6 Composition of macrozoobenthic clusters at selected research positions

\begin{tabular}{|c|c|c|c|c|c|c|}
\hline Class & Order & Family & $\begin{array}{l}\text { Spring } \\
\text { niche no. } 1\end{array}$ & $\begin{array}{l}\text { Horod- } \\
\text { nianka } \\
\text { River }\end{array}$ & $\begin{array}{l}\text { Spring } \\
\text { niche no. } 2\end{array}$ & $\begin{array}{l}\text { Jaro- } \\
\text { szówka } \\
\text { River }\end{array}$ \\
\hline \multirow[t]{3}{*}{ Annelida } & Hirudinea & Erpobdellidae & & 5 & & 7 \\
\hline & & Haemopidae & & 1 & & \\
\hline & Oligochaeta & Oligochaeta & & & 8 & \\
\hline \multirow[t]{2}{*}{ Crustacea } & & Asellidae & & & 8 & 15 \\
\hline & & Gammaridae & 203 & & & \\
\hline \multirow[t]{29}{*}{ Insecta } & Ephemeroptera & Heptagenidae & 1 & & 1 & \\
\hline & & Arthropleidae & & & 1 & \\
\hline & & Ephemerellidae & & & 11 & \\
\hline & & Leptophlebiidae & 29 & & 1 & \\
\hline & & Oligoneuriidae & & & 1 & \\
\hline & Odonata & Calopterygidae & & 1 & & \\
\hline & & Lestidae & & 2 & & \\
\hline & Trichoptera & Polycentropoidae & 18 & & 1 & \\
\hline & & Limnephilidae & 4 & 48 & & 48 \\
\hline & & Ecnomidae & & 5 & 1 & \\
\hline & & Glossosomatidae & & & 15 & \\
\hline & & Goeridae & & 52 & & \\
\hline & & Hydropsychidae & & 13 & 2 & \\
\hline & & Lepidostomatidae & 2 & & 2 & 16 \\
\hline & & Leptoceridae & & & 5 & \\
\hline & & Rhyacophilidae & & & 1 & 8 \\
\hline & & Sericostomatidae & 6 & 1 & & \\
\hline & Coleoptera & Haliplidae & & & & 3 \\
\hline & & Dytiscidae & 2 & 1 & & \\
\hline & & Helodidae & & & 3 & \\
\hline & & Paelobiidae & & & 49 & 12 \\
\hline & & Scirtidae & & & 1 & \\
\hline & Diptera & Tabanidae & 11 & & 1 & \\
\hline & & Chironomidae & & 2 & 46 & 6 \\
\hline & & Ephydridae & & & & 13 \\
\hline & & Limoniidae & & & 6 & \\
\hline & & Sciomyzidae & & & 6 & \\
\hline & Plecoptera & Leuctridae & & & 1 & \\
\hline & Hemiptera & Veliidae & & & 1 & \\
\hline \multirow[t]{2}{*}{ Mollusca } & Gastropoda & Bithynidae & & 2 & & 10 \\
\hline & Bivalvia & Sphaeriidae & 5 & 6 & & \\
\hline \multicolumn{3}{|c|}{ Summary number of species } & 281 & 139 & 172 & 138 \\
\hline \multicolumn{3}{|l|}{ MMI } & 0.83 & 0.79 & 0.89 & 0.63 \\
\hline
\end{tabular}

which deteriorates water quality. This can be seen, for example, in the electrolytic conductivity parameter (values in some places in the spring niche No.2 were over 1000 $\mu \mathrm{S} \mathrm{cm}{ }^{-1}$ ). Moreover, in Jaroszówka River catchment waters were characterized by twice higher concentrations of magnesium and sodium ions and eight times higher concentrations of potassium ions compare to Horodnianka River catchment. This clearly indicates high transformation of water quality and its pollution as a result of leachate filtration from the landfill. In an environment disturbed by humans comes to an imbalance between the components of the water (Szoszkiewicz et al. 2014) so few correlations with the water parameters may suggest less naturalness of the Jaroszówka spring niche ecosystem compared to the Horodnianka sprig niche. A greater transformation of water quality due to human activity in Jaroszówka catchment manifests itself with high EC values. The value of about $2000 \mu \mathrm{S} \mathrm{cm}^{-1}$ in P6 corresponds to the EC values of the waste water (Prieto et al. 2001). This demonstrates the adverse impact of human impact on the quality of both surface and groundwater. 
Table 7 Microbiological characteristics of interstitial water and surface water

\begin{tabular}{llllll}
\hline & Catchment & \multicolumn{4}{l}{ Colony forming unit (CFU) } \\
\cline { 3 - 6 } & & Volume $[\mathrm{mL}]$ & $\begin{array}{l}\text { Interstitial } \\
\text { water }\end{array}$ & Spring & River \\
\hline TVC $22{ }^{\circ} \mathrm{C}$ & Horodnianka River & 1 & 570 & 1500 & $>10,000$ \\
& Jaroszówka River & 1 & 890 & 1800 & $>10,000$ \\
TVC $37{ }^{\circ} \mathrm{C}$ & Horodnianka River & 1 & 120 & 200 & 4500 \\
& Jaroszówka River & 1 & 230 & 400 & 3850 \\
Coliform bacteria & Horodnianka River & 100 & 180 & 250 & 6020 \\
& Jaroszówka River & 100 & 350 & 1960 & 5380 \\
Fecal streptococci & Horodnianka River & 100 & - & 5 & 30 \\
& Jaroszówka River & 100 & 4 & 9 & 27 \\
Clostridium with spores & Horodnianka River & 100 & - & 4 & $>50$ \\
& Jaroszówka River & 100 & - & 8 & $>50$ \\
\hline
\end{tabular}

In the studied spring niches, the groundwater quality changes flowing to the surface were different, depending on the degree of anthropogenization of the environment (Jekatierynczuk-Rudczyk 2010). In interstitial waters, in an anaerobic zone, in the deeper parts of the sediments, nitrates are denitrified. Redox conditions induce nitrification and denitrification processes (Pei et al. 2010). In an aerobic zone, bacteria oxidize ammonium nitrogen to nitrates (Wang et al. 2012). In the HZ, nitrification and ammonification can occur simultaneously, and anaerobic microorganisms can exist even with a large oxygen concentration (Piney et al. 2009, Jekatierynczuk-Rudczyk 2010). The decrease in the concentration of nitrate and ammonium ions in the surface outflow may be caused by imbibition by autotrophic organisms, bacteria and fungi. In spring No. 1, whose bottom is covered with patches of vegetation, the dynamic of redox conditions in the HZ increases the intensity of biogeochemical processes and the transformation of nutrients. There were twice less nitrate ions in the surface water than in interstitial water, which indicates the assimilation of nitrate ions by plants growing on the bottom of the spring niche. Our results confirmed the previously obtained results of nitrogen compound concentration in the springs of the Knyszyńska Forest (Jekatierynczuk-Rudczyk 2010). In spring water and water of streams, the nitrifying bacteria does not occur mostly, so the low nitrate concentration in the outflow water. The factor that limits bacterial growth may be a low water temperature that last throughout the year. The migration of organic matter, including nutrients, is not significantly related with the physical parameters of water, which may also be due to the lack of plant cover in the spring niche in the Jaroszówka River catchment.

In interstitial and surface waters, average TP and SRP concentrations were similar throughout the year. Phosphorus in the form of phosphates is taken up by bacteria, diatoms and macrophytes and accumulated in their organisms in the growing season. The lack of an increase in phosphorus content in surface waters indicates a lack of phosphorus inflow from the catchment or the possibility of its complexation by iron compounds in the water (JekatierynczukRudczyk 2010).

Along the river course, surface water is enriched with allochthonous and autochthonous DOC from a catchment. In interstitial waters there are many processes like the formation of complex compounds on the surface of minerals, adsorbing processes in suspension or incorporation into biomass by organisms inhabiting the HZ (Stegen et al. 2018; Schindler and Krabbenhoft 1998; Zieliński and Jekatierynczuk-Rudczyk 2010). There are many studies indicating the accumulation of DOC in the HZ, as well as indicating the variety of these processes depending water course of the same river (Covino 2017). In interstitial waters, there were about twice as few bacteria as in spring waters. Bacteria consume organic carbon and incorporate it into biomass. In spring No. 2 concentration of DOC was higher in interstitial waters compare to surface waters what can be associated with percolation of organic compounds from landfill. The full vegetation season on July resulted in a slight decomposition of organic matter and resulted high concentration of POC. Bacteria inhabiting the $\mathrm{HZ}$ are able to assimilate both forms of organic carbon (POC and DOC), and biomass production depends on the seasons of the year. For example, in Speed River the number of bacteria is almost three times higher in spring than in summer (Sliva and Williams 2005). No significant relationship between bacterial number and DOC concentration was observed in the studies.

Spring areas often contain significant biodiversity values, including a diverse mixture of cosmopolitan and endemic flora and fauna (Vidakovic et al. 2017; Puczko et al. 2018; Wojtal 2013). The springs studied differed in their richness of organisms, which is associated with varying degrees of human transformation, the physical and chemical parameters of water, the diversity of bottom substrates, their stability and availability of food resources (Kwiatkowska et al. 2016). 
Żelazna-Wieczorek (2011) concluded that human impacts are significant determinants, which contribute to differentiation of diatom assemblages in the springs. The diatom index values indicate a good ecological status of both springs and Jaroszówka River and moderate IO in Horodnianka River (Table 4). There were almost twice as many diatoms in the rivers as in the springs (Table 3 ). This indicates favorable conditions for their development not only in the springs but also in the initial sections of the rivers (Szczepocka et al. 2014). Despite this, diatoms are the most abundant taxon among crenal algal assemblages and represent the largest biomass of primary producers in springs (Kwiatkowska et al. 2016; Rakowska 2001). 27 out of 78 recognized diatoms are of north and alpine preference.

All identified bryophytes are common in river valleys and spring areas of central and eastern Poland (Puczko et al. 2018; Czarnecka 2009; Mazurek 2008). Bioindicator species have been observed here, for example Brachytecium rivulare, whose presence was recorded in spring No.1, is considered a bioindicator of oligotrophy and mesotrophy. In turn, Leptodictyum riparium found in spring No 2 occurs in aquatic ecosystems with a significant degree of anthropogenic transformation. The richness of vascular plants in niches in the suburbs was smaller compared to the flora of lowland springs located in natural areas (Puczko et al. 2018). However, in both niches there were observed Nasturtium officinale. This species is protected in Poland. The typical habitat of Nasturtium officinale are slow flowing shallow waters, river banks, periodically flooded areas and springs. Vascular plants impact on the water quality changes in the initial sections of rivers using biogenic elements, as shown in our research.

Springs differed in the biodiversity of macrozoobenthos. $\mathrm{HZ}$ is a refuge for invertebrates during their early stages of development due to the reduced predator pressure (Robertson and Wood, 2010). No invertebrate family was observed that would occur in both sampling sites (Table 6). The populations of invertebrate species characteristic of waters with good water quality, not only crenophilic ones, were not detected in the Horodnianka river. The sandy riverine habitat is less favorable for Crustacea (Dumnicka et al. 2013), so their abudance were significant lower in Horodnianka compare to spring No. 1 . There are many studies comparing the benthic community structure in springs and in the downstream areas (Dumnicka et al. 2013; Barquin and Death 2011; Von Fumetti et al. 2007). Studies have not confirmed whether species richness increases or decreases along the course of the river. Most likely there is a possibility for both situations or even for the similarity of taxa richness between the spring and river. The factor to consider is a homogenous bottom substrate and low vegetation cover that results less variety of habitats for living. Our research showed that in the spring No. 1, where the bottom of the niche is occupied by patches of vegetation, the largest number of macrozoobenthos was recorded. On the other hand, in the spring No. 2, the heterogeneous bottom affected the diversity of habitats, and greater biodiversity of benthic fauna. This can contribute to greater transformations in water quality.

The number of bacteria increased along the watercourse. The reason for this phenomenon is the inflow of pollution from the catchment area along the surface runoff. Based on the presence of mesophilic and psychrophilic bacteria, as well as other microbiological indicators, it can be concluded that all the groundwater samples tested were bacteriologically contaminated. At the same time, in interstitial waters, the value of the total number of bacteria in the two studied springs testifies to the natural occurrence of bacteria associated with the aquatic environment. In surface waters, there are naturally occurring psychrophilic bacteria that are associated with relatively low temperatures (Zieliński et al. 2020). Their presence in waters is very useful, because they take an active part in the process of self-purification of waters. The high number of psychrophilic bacteria in the waters indicates the richness of the organic substance (Lenart-Boron et al. 2016). They influence natural circulation of organic matter in the microbiological loop. It is a beneficial process by which organic carbon is re-incorporated into trophic networks.

The results regarding the presence of coliforms indicate that water from springs in Horodnianka River and Jaroszówka River catchments cannot be used for drinking. Bacteria belonging to the Clostridium perfringens species are another indicator of water purity, testifying to the presence of impurities that have appeared the most recently. It is widely believed that the presence of these bacteria is a good indicator of water pollution by protozoa of the genus Giardia and Cryptosporidium (Grzyb et al. 2015). Clostridium perfringens was not found in the interstitial waters of the studied springs. This means that the quality of the discussed groundwater is satisfactory.

\section{Conclusions}

The conducted research showed that human activity deteriorates the quality of surface water more than the interstitial water. During surface water supply, the physical and chemical parameters of water change because of the intense metabolism in the HZ, as evidenced by the decrease in the concentration of nitrogen compounds in the outflow. Groundwater upwelling enrich surface water with biogenic compounds, especially DOC and TON.

Comparison of the species richness of fauna and flora in the studied spring niches allows us to conclude that the spring located in the Horodnianka River catchment is characterized by a high degree of naturalness and good ecological status. Hydrophilic vegetation growing on the bottom performs a buffer and stabilizing function by assimilating nitrogen 
compounds from water and contributing to a variation in nutrients concentration.

Small temperature fluctuations in combination with high dynamics of redox conditions increase the intensity of such processes as nitrification, denitrification and ammonification. Those transformations occur one after the other, affecting the variable gradient of nitrogen compounds concentration in interstitial waters in space and time. Hyporheic processes are complex, as evidenced by the mosaic distribution of the amount of organic matter along small streams.

Microbiological analysis of water indicated the presence of psychrophilic bacteria in interstitial waters that influence natural hyporheic processes including circulation of organic matter in the microbiological loop and self-purification of water. Coliforms, Enterococci and Clostridium perfringens were found in spring water, which indicates faecal water contamination and disqualifies water as a potential source of drinking water.

Based on the conducted research, it should be stated that biogeochemical processes occurring in the hyporheic zone of lowland springs in urban areas impact on the quality in the initial sections of urban rivers. However, this impact is various and limited in space. The process of urban transformations of the environment in the initial sections of streams can disturb the natural biogeochemical processes described in the theory of river continuum.

Acknowledgements The authors would like to thank Adam Więcko for assistance with chemical parameters analysis using chromatographic methods in this research project.

Author contributions All authors contributed to the study conception and design. Material preparation, data collection and analysis were performed by Elżbieta Jekatierynczuk-Rudczyk, Katarzyna Puczko, Justyna Żukowska-Stolc and Anna Sawicka. All authors read and approved the final manuscript.

Funding Not applicable.

Availability of data and material All data generated or analysed during this study are available via the Data repository of the University of Białystok. Requests for material should be made to the corresponding author.

\section{Declarations}

Conflict of interest The authors declare that they have no conflict of interest.

Ethics approval Not applicable.

Open Access This article is licensed under a Creative Commons Attribution 4.0 International License, which permits use, sharing, adaptation, distribution and reproduction in any medium or format, as long as you give appropriate credit to the original author(s) and the source, provide a link to the Creative Commons licence, and indicate if changes were made. The images or other third party material in this article are included in the article's Creative Commons licence, unless indicated otherwise in a credit line to the material. If material is not included in the article's Creative Commons licence and your intended use is not permitted by statutory regulation or exceeds the permitted use, you will need to obtain permission directly from the copyright holder. To view a copy of this licence, visit http://creativecommons.org/licenses/by/4.0/.

\section{References}

APHA (1998) Standard methods for the examination of water and wastewater, 19th edn. American Public Health Association, Washington

Barquin J, Death RG (2011) Downstream changes in spring-fed stream invertebrate communities: the effect of increased temperature range? J Limnol 70:134-146

Barquín J, Scarsbrook M (2008) Management and conservation strategies for coldwater springs. Aquat Conserv 18:580-591

Biksey TM, Gross ED (2001) The hyporheic zone: linking groundwater and surface water-understanding the paradigm. Remediation 12(1):55-62

Braun-Blanquet J (1932) Plant sociology. Mcgraw Hill Book Company, Inc, New York

Brunke M, Gonser TOM (1997) The ecological significance of exchange processes between rivers and groundwater. Freshw Biol 37:1-33

Covino T (2017) Hydrologic connectivity as a framework for understanding biogeochemical flux through watersheds and along fluvial networks. Geomorphology 277:133-144

Czarnecka B (2009) Springs of the Roztocze escarpment zone: the diversity of plant cover vs. environment quality. Infrastruct Ecol Rural Areas 6:27-43

Dumnicka E, Galas J, Jatulewicz I, Karlikowska J, Rzonca B (2013) From spring sources to spring brook: changes in environmental characteristics and benthic fauna. Biologia 68:142-149

für Wasserwirtschaft, B. L. (2005). Instruction protocol for the ecological assessment of running waters for implementation of the EU water framework directive: macrophytes and phytobenthos

Górniak A, Jekatierynczuk-Rudczyk E (1997) Anthropogenic changes in spring water quality in the area of the town of Bialystok [Northeastern Poland]. Acta Hydrobiol 39:19-28

Grzyb J, Frączek K, Chmiel MJ (2015) Microbiological threats for groundwater in the impact zone of municipal dumping site. Water-Environment-Rural Areas 15(49):47-58

Heino J, Virtanen R, Vuori KM, Saastamoinen J, Ohtonen A, Muotka T (2005) Spring bryophytes in forested landscapes: land use effects on bryophyte species richness, community structure and persistence. Biol Cons 124(4):539-545

https://www.meteomodel.pl

https://www.xlstat.com/en/news/version-2016-1

Jekatierynczuk-Rudczyk E (1999) Effects of drainage basin management on the chemical composition of waters in lowland springs. Acta Hydrobiol 41:97-105

Jekatierynczuk-Rudczyk E (2007) Hyporheic zone, its functioning and meaning. Kosmos 1:181-196

Jekatierynczuk-Rudczyk E (2008) Threats to a small river and its urban catchment. Ecohydrol Hydrobiol 8:77-87

Jekatierynczuk-Rudczyk E (2010) Transformation in physicochemical composition of groundwater within lowland drainage zones. Białystok, Wyd. UwB, 224

Knapp JLA, González-Pinzón R, Haggerty R (2018) The resazurinresorufin system: Insights from a decade of "Smart" tracer development for hydrologic applications. Water Resour Res 54:6877-6889 
Krammer K, Lange-Bertalot H (1986) Bacillariophyceae 1. Teil, Naviculaceae. In: Ettl H, Gerloff J, Heynig H, Mollenhauer D (eds) Süßwasserflora von Mitteleuropa, vol 2. Springer, New York

Krammer K, Lange-Bertalot H (1991a) Bacillariophyceae 3. Teil, Centrales, Fragilariaceae, Eunotiaceae. In: Ettl H, Gerloff J, Heynig H, Mollenhauer D (eds) Süßwasserflora von Mitteleuropa, vol 2. Springer, New York

Krammer K, Lange-Bertalot H (1991b) Bacillariophyceae 4. Teil, Achnanthaceae, kritische Ergänzungen zu Navicula (Lineolatae) und Gomphonema. In: Ettl H, Gerloff J, Heynig H, Mollenhauer D (eds) Süßwasserflora von Mitteleuropa, vol 2. Springer, New York

Krammer K, Lange-Bertalot H (1997) Bacillariophyceae 2. Teil, Bacillariaceae, Epithemiaceae, Surirellaceae. In: Ettl H, Gerloff J, Heynig H, Mollenhauer D (eds) Süßwasserflora von Mitteleuropa, vol 2. Springer, Heidelberg

Krause S, Hannah DM, Fleckenstein JH, Heppell CM, Kaeser D, Pickup R et al (2011) Inter-disciplinary perspectives on processes in the hyporheic zone. Ecohydrol 4:481-499

Kwiatkowska K, Żelazna-Wieczorek J, Ziułkiewicz M (2016) Caddisflies (Trichoptera) and diatoms of some springs in the vicinity of Łódź (Central Poland). Zootaxa 4138(1):118-126

Lawrence JE, Skold ME, Hussain FA, Silverman DR, Resh VH, Sedlak DL et al (2013) Hyporheic zone in urban streams: a review and opportunities for enhancing water quality and improving aquatic habitat by active management. Environ Eng Sci 30:480-501

Lenart-Boroń A, Wolanin A, Jelonkiewicz Ł, Chmielewska-Błotnicka D, Żelazny M (2016) Spatiotemporal variability in microbiological water quality of the Białka River and its relation to the selected physicochemical parameters of water. Water Air Soil Pollut 227:22

Lewin I, Jusik Sz, Szoszkiewicz K, Czerniawska-Kusza I, Ławniczak AE (2014) Application of the new multimetric MMI-PL index for biological water quality assessment in reference and humanimpacted streams (Poland, the Slovak Republic). Limnologica 49:42-51

Mazurek M (2008) Spring niches areas with a link between the cone system and the trough system, the Parsęta river basin. Landf Anal 9:63-67

Mirek Z, Piekos-Mirkowa H, Zajac A, Zajac M (2002). Flowering plants and pteridophytes of Poland. A checklist. W. Szafer Institute of Botany, PAN

Ochyra R, Żarnowiec J, Bednarek-Ochyra H (2003) Genus catalogue of polish mosses: biodiversity of Poland, vol 3. Polish Academy of Sciences, Kraków

Pei YS, Wang J, Wang ZY, Yang ZF (2010) Characteristics of ammonia-oxidizing and denitrifying bacteria at the river-sediment interface. Proc Environ Sci 2:1988-1996

Picińska-Fałtynowicz J, Błachuta J, Kotowicz J, Mazurek M, Rawa W (2006) Selection of river and lake water bodies for the assessment of the ecological status on the basis of phytobenthos together with a recommendation of the sampling methodology and analysis. National Research Institute, Wrocław, pp 1-34

Piney G, O'Keefe TC, Edwards RT, Naiman RJ (2009) Nitrate removal in the hyporheic zone of a salmon river in Alaska. River Res Appl 25:367-375

Prieto F, Barrado E, Vega M, Deban L (2001) Measurement of electrical conductivity of wastewater for fast determination of metal ion concentration. Russ J Appl Chem 74(8):1321-1324

Puczko K, Jekatierynczuk-Rudczyk E (2020) Analysis of urban land cover influence to organic carbon and nutrients in surface water via impacted groundwater. Environ Monit Assess 192:145

Puczko K, Zieliński P, Jusik Sz, Kołakowska A, Jekatierynczuk-Rudczyk E (2018) Vascular plant and bryophyte species richness in response to water quality in lowland spring niches with different anthropogenic impacts. Environ Monit Assess 190:338
Rakowska B (2001) Indicatory values in ecological description of diatoms from Polish lowlands. Int J Ecohydrol Hydrobiol 4(01):481-502

Robertson AL, Wood PJ (2010) Ecology of the hyporheic zone: origins, current knowledge and future directions. Fund Appl Limnol 176:279-289

Rott E, Hofmann G, Pall K, Pfister P, Pipp E (1997) Indikationslisten für Aufwuchsalgen. Teil 2: Trophieindikation, geochemische Reaktion, toxikologische und taxonomische Anmerkungen. Publ. Wasserwirtschaftskataster, BMLF, pp 1-248

Rott E, Binder N, Van Dam H, Ortler K, Pall K, Pfister P, Pipp E (1999) Indikationslisten für Aufwuchsalgen. Teil 2: Trophieindikation, geochemische Reaktion, toxikologische und taxonomische Anmerkungen. Publ. Wasserwirtschaftskataster, BMLF, pp 1-248.

Schindler JE, Krabbenhoft DP (1998) The hyporheic zone as a source of dissolved organic carbon and carbon gases to a temperate forested stream. Biogeochemistry 43:157-174

Sliva L, Williams DD (2005) Exploration of riffle-scale interactions between abiotic variables and microbial assemblages in the hyporheic zone. Can J Fish Aquat Sci 62:276-290

Sojka M, Kozłowski M, Kęsicka B, Wróżyński R, Stasik R, Napierała $M$ et al (2020) The effect of climate change on controlled drainage effectiveness in the context of groundwater dynamics, surface, and drainage uutflows. Central-Western Poland case study. Agronomy 10(5):625

Stegen JC, Johnson T, Fredrickson JK, Wilkins MJ, Konopka AE, Nelson WC et al (2018) Influences of organic carbon speciation on hyporheic corridor biogeochemistry and microbial ecology. Nat Commun 9:1-11

Szczepocka E, Szulc B, Szulc K, Rakowska B, Żelazna-Wieczorek J (2014) Diatom indices in the biological assessment of the water quality based on the example of a small lowland river. Oceanol Hydrobiol Stud 43(3):265-273

Szoszkiewicz K, Zbierska J, Jusik Sz, Zgoła T (2010) Macrophyte method for river assessment-manual for the assessment and classification of ecological status of running waters based on the aquatic plants. Bogucki Scientific Publishing, Poznań

Szoszkiewicz K, Ciecierska H, Kolada A, Schneider SC, Szwabińska M, Ruszczyńska J (2014) Parameters structuring macrophyte communities in rivers and lakes-results from a case study in North-Central Poland. Knowl Manag Aquat Ecosyst 415:08

Szweykowski J (2006) An annotated checklist of Polish liverworts and hornworts. Biodiversity of Poland, vol 4. Polish Academy of Sciences, Kraków

Vidakovic D, Cantonati M, Mogna M, Jakovljević O, Šovran S, Lazović V, Krizmanić J (2017) Additional information on the distribution and ecology of the recently described diatom species Geissleria gereckei. Oceanol Hydrobiol Stud 46(1):18-23

Von Fumetti S, Nagel P, Baltes B (2007) Where a spring-head becomes a springbrooks - a regional zonation of springs. Arch Hydrobiol Fund Appl Limnol 169:37-48

Wang ZQiY, Wang J, Pei Y (2012) Characteristics of aerobic and anaerobic ammonium-oxidizing bacteria in the hyporheic zone of a contaminated river. World J Microb Biot 28:2801-2811

Ward AS (2016) The evolution and state of interdisciplinary hyporheic research. Wiley Interdiscip Rev Water 3:83-103

Wojtal AZ (2013) Species composition and distribution of diatom assemblages in spring waters from various geological formations in southern Poland. Cramer, Stuttgart

Xing X, Chen M, Wu Y, Tang Y, Li C (2021) The decomposition of macrozoobenthos induces large releases of phosphorus from sediments. Environ Pollut 283:117104

Żelazna-Wieczorek J (2011). In: Witkowski A (ed) Diatom flora in springs of Łódź Hills (Central Poland). Biodiversity, taxonomy and temporal changes of epipsammic diatom assemblages in 
springs affected by human impact, vol 13. A.R.G. Gantner Verlag K.G. Ruggell, Liechtenstein, pp 1-420

Zhu A, Yang Z, Liang Z, Gao L, Li R, Hou L et al (2020) Integrating hydrochemical and biological approaches to investigate the surface water and groundwater interactions in the hyporheic zone of the Liuxi River basin, southern China. J Hydrol 583:124622

Zieliński P, Jekatierynczuk-Rudczyk E (2010) Dissolved organic matter transformation in the hyporheic zone of a small lowland river. Oceanol Hydrobiol Stu 39:97-103

Zieliński P, Jekatierynczuk-Rudczyk E, Puczko K (2020) Factors affecting the abundance and activity of the bacterioplankton in lowland forest springs in north-eastern Poland. Ecohydrol Hydrobiol 20(4):675-686

Publisher's Note Springer Nature remains neutral with regard to jurisdictional claims in published maps and institutional affiliations. 